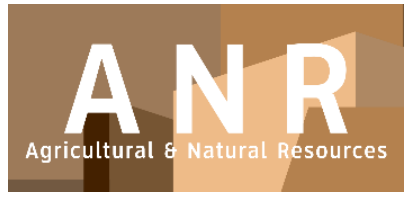

PAPER - OPEN ACCESS

\title{
Aplikasi Beberapa Bahan Organik dan Lamanya Inkubasi Dalam Meningkatkan P-Tersedia Tanah Ultisol
}

\author{
Author : Nita Rentina Pasaribu \\ DOI $\quad: 10.32734 /$ anr.v1i1.129 \\ Electronic ISSN : :2654-7023 \\ Print ISSN : 2654-7015
}

Volume 1 Issue 2 - 2018 TALENTA Conference Series: Agricultural \& Natural Resources (ANR)

\section{(2) $(1)$}

This work is licensed under a Creative Commons Attribution-NoDerivatives 4.0 International License.

Published under licence by TALENTA Publisher, Universitas Sumatera Utara
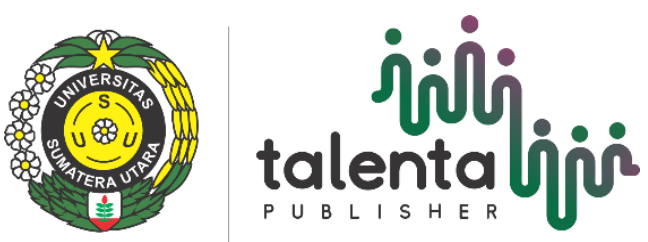


\section{indi \\ talentaliopis}

\title{
TALENTA Conference Series
}

Available online at https://talentaconfseries.usu.ac.id

\author{
Nita Rentina Pasaribu ${ }^{\mathrm{a}, *}$, Fauzi $^{\mathrm{a}}$, Asmarlaili Sahar Hanafiah ${ }^{\mathrm{a}}$ \\ ${ }^{a}$ Fakultas Pertanian, Universitas Sumatera Utara, Medan 20155, Indonesia \\ tarentipasaribu@yahoo.com
}

\begin{abstract}
Abstrak
Ultisol merupakan bagian terluas dari lahan kering yang ada di Indonesia yaitu sekitar 25\% dari total daratan Indonesia. Tanah yang mempunyai kesuburan rendah karena bereaksi masam, kandungan bahan organik rendah, kadar hara $\mathrm{P}$ rendah dan kelarutan Al yang tinggi. Penelitian ini bertujuan untuk mengetahui pengaruh pemberian beberapa bahan organik dan lamanya inkubasi terhadap peningkatan pH, P-tersedia, kapasitas tukar kation (KTK), penurunan Al-dd dan kejenuhan Al pada tanah Ultisol yang dilaksanakan di Laboratorium Fisika Tanah, Fakultas Pertanian, Universitas Sumatera Utara dan Laboratorium Socfin Indonesia, Medan. Penelitian ini menggunakan Rancangan Acak Lengkap Faktorial dengan 2 faktor dan 3 ulangan. Faktor pertama adalah bahan organik terdiri dari kontrol (B0), kompos Tithonia diversifolia (paitan) (B1), kompos kulit durian (B2), kompos TKKS (B3), pupuk kandang ayam (B4), kompos paitan + pukan ayam (B5), kompos kulit durian + pukan ayam (B6), kompos TKKS + pukan ayam (B7). Faktor kedua adalah lama inkubasi terdiri dari inkubasi satu minggu (I1), inkubasi dua minggu (I2). Hasil penelitian ini menunjukkan bahwa pemberian bahan organik nyata meningkatkan $\mathrm{pH}, \mathrm{P}$-tersedia, KTK serta menurunkan Al-dd dan kejenuhan Al. Lama inkubasi nyata menurunkan $\mathrm{pH}$ tetapi tidak mempengaruhi P-tersedia, KTK, menurunkan Al-dd dan kejenuhan Al, serta interaksi bahan oganik dengan lamanya inkubasi nyata menurunkan Al-dd tanah tetapi tidak mempengaruhi pH, P-tersedia, KTK, dan menurunkan kejenuhan Al.
\end{abstract}

Kata Kunci: Bahan organik; inkubasi; P-tersedia dan tanah Ultisol;

\section{Pendahuluan}

Ultol merupakan bagian terluas dari lahan kering yang ada di Indonesia yaitu sekitar $25 \%$ dari total daratan Indonesia dan sebagian besar digunakan sebagai lahan pertanian. Namun demikian, dari warna tanah yang merah kekuningan menunjukkan bahwa tanah ini memiliki kandungan bahan organik yang rendah, reaksi tanah yang masam, kejenuhan basa rendah, kadar Al yang tinggi dan produktivitas tanah yang rendah. Oleh karena itu, pengelolaan kesuburan tanah Ultisol perlu mendapat perhatian.

Permasalahan utama yang dihadapi pada Ultisol jika dijadikan lahan pertanian adalah rendahnya unsur hara Fosfor yang tersedia. Kekurangan unsur hara $\mathrm{P}$ dalam tanah Ultisol disebabkan oleh terikatnya P secara kuat oleh mineral lempung dan oksida-oksida besi dan aluminium membentuk Al-P dan Fe-P tidak larut sehingga menjadi tidak tersedia untuk tanaman. Abdurachman, et al. [1] menyatakan tanah Ultisol tersebut umumnya dijumpai sebagai lahan kering masam yang mempunyai kesuburan yang rendah karena kandungan bahan organik yang rendah dan tingginya kelarutan Aluminium dan rendahnya kadar hara P dan Ca serta Mg dalam tanah.

Salah satu upaya yang dapat dilakukan untuk mengatasi masalah tersebut adalah dengan penambahan bahan organik seperti kompos paitaN (Tithonia diversifolia), kompos kulit durian, kompos tandan kosong kelapa sawit (TKKS) dan pupuk kandang ayam. Hasil penelitian Hakim dan Agustian (2012) menyatakan bahwa kompos paitan 
meningkatkan $\mathrm{pH}$ tanah dari 4,69 menjadi 5,01 dan menurunkan Al-dd tanah sebesar 1,00 me/100 g tanah. Aplikasi kompos kulit durian meningkatkan $\mathrm{pH}$ tanah dari 4,78 menjadi 5,04 dan menurunkan Al-dd tanah dari 3,57 menjadi $0,64 \mathrm{me} / 100 \mathrm{~g}$ tanah [4]. Selanjutnya penelitian Wiwie [17] mengemukakan pemberian pupuk kandang ayam dapat meningkatkan $\mathrm{pH}$ tanah sebesar 0,37, $\mathrm{N}$ total sebesar 0,242\% dan P tersedia sebesar 5,9 ppm, sedangkan Al-dd tanah menurun sebesar 1,78 me/100 g tanah. Demikian pula dengan aplikasi kompos TKKS meningkatkan P-Bray II tanah dari 4 ppm menjadi 10 ppm [7].

Bahan organik yang diberikan pada tanah memerlukan waktu dalam proses perombakan oleh mikroorganisme. Masa inkubasi sangat menentukan kematangan dari suatu kompos. Apabila masa inkubasi belum cukup, maka kompos yang dihasilkan kualitasnya kurang baik bila digunakan sebagai pupuk.

\section{Bahan dan Metode}

Penelitian ini dilaksanakan di Laboratorium Fisika Tanah Fakultas Pertanian Uiversitas Sumatera Utara dan analisis tanah dilakukan di Laboratorium Socfin Indonesia Medan, dimulai dari Desember 2015 sampai dengan selesai.

Bahan yang digunakan untuk penelitian ini adalah contoh tanah Ultisol yang diambil di Desa Kampung Dalam, Kecamatan Silangkitan, Kabupaten Labuhan Batu Selatan, Provinsi Sumatera Utara pada kedalaman 0-20 cm secara komposit, bahan organik berupa kompos paitan, kompos TKKS, kompos kulit durian, pupuk kandang ayam serta bahan kimia yang digunakan untuk analisis tanah di Laboratorium.

Alat yang digunakan untuk penelitian ini adalah cangkul, pot plastik, kantong plastik, kertas label, spidol, pH meter, plastik bening, gelas ukur, timbangan dan alat-alat Laboratorium untuk keperluan analisis tanah.

Penelitian ini menggunakan Rancangan Acak Lengkap Faktorial dengan 2 faktor dan 3 ulangan. Faktor pertama adalah bahan organik terdiri dari kontrol (B0), kompos Tithonia diversifolia (paitan) (B1), kompos kulit durian (B2), kompos TKKS (B3), pupuk kandang ayam (B4), kompos paitan + pukan ayam (B5), kompos kulit durian + pukan ayam (B6), kompos TKKS + pukan ayam (B7). Faktor kedua adalah lama inkubasi terdiri dari inkubasi satu minggu (I1), inkubasi dua minggu (I2).

Peubah amatan yang diamati adalah pH H2O metode Elektrometri, P-tersedia ( $\mathrm{ppm}$ ) tanah dengan metode Bray II, Kapasitas Tukar Kation (KTK) metode 1 N NH4OAc pH 7, Al-dd (me/100 g) metode KCl 1 N dan Kejenuhan Al $(\%)$.

Pelaksanaan penelitian dimulai dari persiapan dan penanganan contoh tanah yang diambil dari desa Kampung Dalam, Kecamatan Silangkitan, Kabupaten Labuhan Batu Selatan, secara komposit dengan kedalaman 0-20 cm, kemudian dikering udarakan, diayak dengan menggunakan ayakan pasir 10 mesh dan dimasukkan ke dalam pot plastik sebanyak $5 \mathrm{~kg}$ berat tanah kering oven, selanjutnya dilakukan analisis tanah awal. Pengomposan dilakukan secara manual, paitan, kulit durian dan tandan kosong kelapa sawit dicacah menjadi potongan-potongan kecil dan diletakkan pada wadah yang tersedia, lalu diberikan EM-4 (Effective Microorganism 4) untuk mempercepat proses pengomposan. Wadah ditutup dengan plastik untuk menjaga suhu dan kelembaban, dibolak balik setiap satu minggu sekali, serta dilakukan penyiraman setiap dua hari sekali. Pukan ayam diperoleh dari peternakan ayam dan dikering udarakan. Selanjutnya dilakukan analisis kompos dan pukan ayam yaitu \%KA, pH H2O, \%C, \%N, rasio C/N dan Ptotal. Kompos dan pukan ayam diaplikasikan sesuai perlakuan yaitu selama 1 minggu dan 2 minggu. Penyiraman menggunakan aquades dilakukan satu kali sehari sesuai dengan kapasitas lapang.

Pengambilan sampel dilakukan setelah masa inkubasi selesai (1 minggu dan 2 minggu) dan dikering udarakan. Sampel yang diambil dari setiap perlakuan adalah sebanyak 500 gr, lalu sampel tanah dimasukkan ke dalam plastik bening. 


\section{Hasil Dan Pembahasan}

\section{1. pH Tanah}

Rataan $\mathrm{pH}$ tanah Ultisol akibat pemberian beberapa bahan organik dan lamanya inkubasi dapat dilihat pada Tabel 1 dibawah ini :

Tabel 1. Rataan nilai reaksi tanah $(\mathrm{pH} \mathrm{H} 2 \mathrm{O})$ pada aplikasi bahan oganik dan lamanya inkubasi

\begin{tabular}{llll}
\hline & Lama Inkubasi & & Rataan \\
\hline Perlakuan & I1 & I2 & $(2$ minggu) \\
\hline B0 (kontrol) & $(1$ minggu) & 5,76 & $5,75 \mathrm{f}$ \\
B1 (kompos paitan) & 5,73 & 7,06 & $7,07 \mathrm{ab}$ \\
B2 (kompos kulit durian) & 7,09 & 7,07 & $7,25 \mathrm{ab}$ \\
B3 (kompos TKKS) & 7,42 & 6,21 & $6,51 \mathrm{de}$ \\
B4 (pukan ayam) & 6,81 & 7,21 & $7,37 \mathrm{a}$ \\
B5 (kompos paitan + pukan ayam) & 7,54 & 6,75 & $7,01 \mathrm{bc}$ \\
B6 (kompos kulit durian + pukan ayam) & 7,26 & 6,61 & $6,76 \mathrm{~cd}$ \\
B7 (kompos TKKS + pukan ayam) & 6,91 & 6,11 & $6,24 \mathrm{e}$ \\
\hline Rataan & 6,37 & $6,60 \mathrm{~b}$ & \\
\hline
\end{tabular}

Keterangan : Angka yang diikuti oleh huruf yang tidak sama berarti berbeda nyata menurut Uji DMRT pada taraf $5 \%$

Pada Tabel 1 berdasarkan hasil analisis diperoleh bahwa nilai $\mathrm{pH}$ tanah tertinggi adalah pada aplikasi pupuk kandang ayam yaitu 7,37 dengan kriteria netral. Aplikasi bahan organik berupa pupuk kandang ayam kedalam tanah menghasilkan asam-asam organik yang dapat membentuk senyawa komplek stabil (khelasi) dan menurunkan kandungan Al dalam tanah Ultisol. Menurut Riyaldi [13] penambahan bahan organik mampu meningkatkan $\mathrm{pH}$ tanah dan mampu menurunkan $\mathrm{Al}$ tanah.

Hasil penelitian menunjukkan bahwa pH tanah tertinggi terdapat pada perlakuan B4 (pupuk kandang ayam) sebesar 7,37 dengan kriteria netral. Nilai pH tersebut mengalami peningkatan dari pH kontrol (B0) yaitu 5,75 yang artinya bahwa pupuk kandang ayam yang hasil dekomposisi menghasilkan asam-asam organik yang dapat mengikat ion $\mathrm{H}+$ sebagai penyebab kemasaman dalam tanah sehingga pH tanah akan meningkat. Menurut Scnitzer [14] asam-asam organik dapat mengikat ion $\mathrm{H}+$ melalui gugus karboksil yang memiliki muatan negatif dengan reaksi berikut :<smiles>[R]C([NH3+])C(=O)[O-]</smiles><smiles>C=CC1CC1</smiles><smiles>[R]C([NH3+])C(=O)O</smiles>

Pengaruh lamanya inkubasi bahan organik berpengaruh nyata terhadap $\mathrm{pH}$ tanah. Pada inkubasi 1 minggu $\mathrm{pH}$ tanah yaitu 6,89 dan inkubasi 2 minggu 6,60. Dari hasil penelitian dapat dilihat bahwa semakin lama inkubasi tidak menentukan semakin tinggi $\mathrm{pH}$ tanah, $\mathrm{pH}$ akan meningkat apabila bahan organik telah terdekomposisi sempurna. Hasil penelitian Yue, et al. [18] menunjukkan bahwa mineralisasi bahan organik terjadi selama proses inkubasi. Manurung [10] menjelaskan peningkatan $\mathrm{pH}$ tanah akan terjadi apabila bahan organik yang diaplikasikan telah terdekomposisi lanjut (matang) karena bahan organik yang telah termineralisasi akan melepaskan mineralnya berupa kation-kation basa. 


\subsection{P-tersedia}

Rataan P-tersedia tanah Ultisol akibat pemberian beberapa bahan organik dan lamanya inkubasi dapat dilihat pada Tabel 2 dibawah ini :

Tabel 2. Rataan nilai P-tersedia (ppm) tanah pada aplikasi bahan oganik dan lamanya inkubasi

\begin{tabular}{llll}
\hline & Lama Inkubasi & & \\
\hline Perlakuan & I1 & I2 & Rataan \\
\hline B0 (kontrol) & $(1$ minggu) & $(2$ minggu) & \\
B1 (kompos paitan) & 12,76 & 16,43 & $26,60 \mathrm{~d}, 29 \mathrm{ab}$ \\
B2 (kompos kulit durian) & 25,78 & 26,80 & $21,60 \mathrm{bc}$ \\
B3 (kompos TKKS) & 21,62 & 21,58 & $18,74 \mathrm{~cd}$ \\
B4 (pukan ayam) & 17,41 & 20,06 & $23,07 \mathrm{abc}$ \\
B5 (kompos paitan + pukan ayam) & 20,74 & 25,39 & $28,02 \mathrm{a}$ \\
B6 (kompos kulit durian + pukan ayam) & 27,28 & 28,75 & $20,44 \mathrm{bc}$ \\
B7 (kompos TKKS + pukan ayam) & 21,21 & 19,67 & $24,40 \mathrm{abc}$ \\
\hline Rataan & 24,14 & 24,66 & 22,92 \\
\hline
\end{tabular}

Keterangan : Angka yang diikuti oleh huruf yang tidak sama berarti berbeda nyata menurut Uji DMRT pada taraf $5 \%$

Tanah Ultisol merupakan tanah yang bereaksi masam, kandungan Al yang tinggi dan unsur hara yang rendah terutama P. Berikut reaksi tanah Ultisol yang memiliki kadar Al dan Fe tinggi yang menyebabkan keasaman tanah :

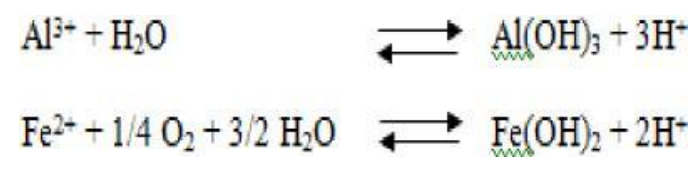

Asam-asam organik yang dihasilkan pelapukan bahan organik akan mengikat $\mathrm{Al}^{3+}$ dan $\mathrm{Fe}^{2+}$ sehingga mampu meningkatkan $\mathrm{pH}$ tanah dan mampu menurunkan kadar $\mathrm{Al}$ tanah sehingga $\mathrm{P}$ yang terikat oleh logam dapat terlepas dari ikatan dan menjadi tersedia. Hardjowigeno [9] menambahkan bahwa pada tanah masam unsur P tidak dapat diserap tanaman karena diikat (difiksasi) oleh $\mathrm{Al}$ dan pada $\mathrm{pH}$ netral unsur hara akan mudah larut dalam air.

Hasil penelitian pada Tabel 2 menunjukkan bahwa perlakuan kompos paitan + pukan ayam $\left(\mathrm{B}_{5}\right)$ memberikan rataan tertinggi yaitu sebesar 28,02 ppm yang termasuk dalam kriteria tinggi pengukuran $\mathrm{pH}$ pada perlakuan $\mathrm{B}_{5}$ sebesar 7,01 dimana $\mathrm{pH}$ mencapai netral yang artinya kandungan $\mathrm{OH}$ - dan $\mathrm{H}+$ seimbang, sehingga $\mathrm{Al}$ tidak lagi mengikat unsur $\mathrm{P}$ dan menjadi tersedia dalam tanah. Engelstad [6] menyatakan bahwa $\mathrm{pH}$ tanah mempengaruhi ketersediaan $\mathrm{P}$, dalam kisaran $\mathrm{pH} 5 \mathrm{~s} / \mathrm{d} 7,2$ bentuk ion $\mathrm{P}$ yang dominan adalah $\mathrm{H}_{2} \mathrm{PO}_{4}$.

Pada Tabel 2 dapat dilihat rata-rata peningkatan $\mathrm{P}$ tersedia tanah Ultisol pada penambahan bahan organik berupa kompos dan pukan ayam dan tanpa pemberian bahan organik, perlakuan B5 (kompos paitan + pukan ayam) adalah yang tertinggi diantara seluruh perlakuan. Kompos paitan dan pukan ayam yang mengandung unsur hara $\mathrm{P}$ masingmasing 0,29\% $\mathrm{P}$ dan 2,9\% $\mathrm{P}_{2} \mathrm{O} 5$, dari masing-masing bahan organik menyumbang unsur hara $\mathrm{P}$ ke dalam tanah. 


\subsection{Kapasitas Tukar Kation (KTK)}

Rataan KTK tanah Ultisol akibat pemberian beberapa bahan organik dan lamanya inkubasi dapat dilihat pada Tabel 3 dibawah ini:

Tabel 3. Rataan nilai KTK (me/100g) tanah pada aplikasi bahan oganik dan lamanya inkubasi

\begin{tabular}{llll}
\hline & Lama Inkubasi & & Rataan \\
\hline Perlakuan & I1 & I2 & $(2$ minggu) \\
\hline B0 (kontrol) & $(1$ minggu) & 3,84 & $4,14 \mathrm{~d}$ \\
B1 (kompos paitan) & 4,44 & 5,11 & $5,51 \mathrm{bc}$ \\
B2 (kompos kulit durian) & 5,90 & 7,07 & $7,76 \mathrm{a}$ \\
B3 (kompos TKKS) & 8,46 & 5,37 & $5,82 \mathrm{~b}$ \\
B4 (pukan ayam) & 6,27 & $4,57 \mathrm{~cd}$ \\
B5 (kompos paitan + pukan ayam) & 4,77 & 4,79 & $4,75 \mathrm{bcd}$ \\
B6 (kompos kulit durian + pukan ayam) & 4,72 & 4,67 & $5,31 \mathrm{bc}$ \\
B7 (kompos TKKS + pukan ayam) & 5,94 & 6,20 & $5,46 \mathrm{bc}$ \\
\hline Rataan & 4,72 & 5,20 & \\
\hline
\end{tabular}

Keterangan : Angka yang diikuti oleh huruf yang tidak sama berarti berbeda nyata menurut Uji DMRT pada taraf $5 \%$

Dari hasil penelitian diperoleh bahwa perlakuan kompos kulit durian (B2) adalah perlakuan yang tertinggi yang dapat menaikkan KTK tanah Ultisol yaitu sebesar 7,76 me/100 dan masih tergolong dalam kategori rendah. Hal ini berkaitan dengan bahan organik dapat menyumbang unsur hara walaupun dalam jumlah sedikit, bahan organik juga menyumbangkan koloid-koloid tanah yang dapat mengikat kation-kation sehingga dapat meningkatkan Kapasitas Tukar Kation (KTK) tanah.

Pada Tabel 3 dapat dilihat bahwa KTK tanah meningkat dengan adanya penambahan bahan organik daripada kontrol. Harada (2012) menyatakan bahwa kadar kapasitas tukar kation (KTK) tanah dipengaruhi oleh mineral liat dan bahan organik tanah, bahkan bahan organik lebih sering menyumbangkan KTK tanah lebih besar dari pada mineral liat. Ditambahkan oleh Mukhlis, et al. (2011) sebagian bahan organik merupakan humus yang berperan sebagai koloid tanah yang dapat meningkatkan KTK tanah.

\subsection{Aluminium dapat dipertukarkan (Al-dd)}

Rataan nilai Al-dd tanah Ultisol akibat pemberian bahan organik dan lamanya inkubasi dapat dilihat pada Tabel 4 dibawah ini :

Tabel 4. Rataan nilai Al-dd (me/100g) tanah pada aplikasi bahan oganik dan lamanya inkubasi

\begin{tabular}{llll}
\hline & Lama Inkubasi & & \\
\hline Perlakuan & I1 & I2 & Rataan \\
& $(1$ minggu $)$ & $(2$ minggu $)$ & \\
\hline B0 (kontrol) & $0,66 \mathrm{a}$ & $0,52 \mathrm{~b}$ & $0,59 \mathrm{a}$ \\
B1 (kompos paitan) & $0,49 \mathrm{bc}$ & $0,44 \mathrm{bcd}$ & $0,46 \mathrm{~b}$ \\
B2 (kompos kulit durian) & $0,40 \mathrm{~cd}$ & $0,35 \mathrm{~d}$ & $0,37 \mathrm{~b}$ \\
B3 (kompos TKKS) & $0,03 \mathrm{f}$ & $0,04 \mathrm{f}$ & $0,04 \mathrm{f}$ \\
B4 (pukan ayam) & $0,06 \mathrm{f}$ & $0,16 \mathrm{e}$ & $0,11 \mathrm{e}$
\end{tabular}




\begin{tabular}{llll} 
B5 (kompos paitan + pukan ayam) & $0,03 \mathrm{f}$ & $0,03 \mathrm{f}$ & $0,03 \mathrm{f}$ \\
B6 (kompos kulit durian + pukan ayam) & $0,00 \mathrm{f}$ & $0,03 \mathrm{f}$ & $0,01 \mathrm{f}$ \\
B7 (kompos TKKS + pukan ayam) & $0,03 \mathrm{f}$ & $0,00 \mathrm{f}$ & $0,01 \mathrm{f}$ \\
\hline Rataan & 0,21 & 0,19 & \\
\hline
\end{tabular}

Keterangan : Angka yang diikuti oleh huruf yang tidak sama berarti berbeda nyata menurut Uji DMRT pada taraf $5 \%$.

Tabel 4 menunjukkan rataan nilai Al-dd tanah Ultisol setelah diaplikasikan bahan organik, dapat dilihat bahwa perlakuan B6 (kompos kulit durian + pukan ayam) dan B7 (kompos TKKS + pukan ayam) mampu menurunkan kadar Al-dd dalam tanah dari kadar Al-dd kontrol sebesar 0,59 me/100 menurun menjadi 0,01 me/100. Perlakuan B6 dan B7 mempunyai pH masing-masing 6,76 dan 6,24 dimana pH dan Al-dd berbanding terbalik, semakin meningkat $\mathrm{pH}$ tanah maka Al-dd dalam tanah semakin rendah. Tan (2010) menyatakan bahwa peran kompos dalam menurunkan Al yang dapat dipertukarkan disebabkan karena pemberian kompos ke dalam tanah akan menghasilkan asam-asam organik yang akan membentuk senyawa khelat dengan Al bebas didalam tanah sehingga Al yang dipertukarkan dapat menurun.

Dari hasil penelitian pada Tabel 4 menunjukkan bahwa perlakuan B6 (kompos kulit durian + pukan ayam dengan lama inkubasi 1 minggu) dan B7 (kompos TKKS + pukan ayam dengan lama inkubasi 2 minggu) menurunkan kandungan Aluminium dapat dipertukarkan sampai sebesar 0 me/100 (tidak terdeteksi). Dapat dilihat bahwa lamanya inkubasi berpengaruh tidak nyata menurunkan Al-dd, namun bahan organik mampu menurunkan Al-dd dalam tanah.

Dari Tabel 2 pada P tersedia tanah dapat dilihat bahwa unsur hara P tersedia dalam tanah sebesar 18,74 ppm yang termasuk dalam kriteria sedang. Hasil penelitian ini menunjukkan bahwa semakin rendah Aluminium dapat dipertukarkan dalam tanah maka semakin besar unsur hara terlepas dari ikatan logam Al. Selain itu juga kompos TKKS dapat menyumbangkan unsur hara $\mathrm{P}$ ke dalam tanah sebesar 0,22\% $\mathrm{P}_{2} \mathrm{O} 5$ [5].

\subsection{Kejenuhan $\mathrm{Al}$}

Rataan nilai kejenuhan $\mathrm{Al}(\%)$ tanah Ultisol akibat pemberian bahan organik dan lamanya inkubasi dapat dilihat pada Tabel 5 dibawah ini :

Tabel 5. Rataan nilai kejenuhan $\mathrm{Al}(\%)$ tanah pada aplikasi bahan oganik dan lamanya inkubasi

\begin{tabular}{llll}
\hline & \multicolumn{2}{l}{ Lama Inkubasi } & \\
\cline { 2 - 4 } Perlakuan & I1 & Rataan \\
& $(1$ minggu) & $(2$ minggu) & $14,46 \mathrm{a}$ \\
\hline B0 (kontrol) & 15,25 & 13,68 & $8,46 \mathrm{~b}$ \\
B1 (kompos paitan) & 8,25 & 8,66 & $4,82 \mathrm{~d}$ \\
B2 (kompos kulit durian) & 4,74 & 4,90 & $0,63 \mathrm{ef}$ \\
B3 (kompos TKKS) & 0,59 & 0,67 & $2,31 \mathrm{e}$ \\
B4 (pukan ayam) & 1,17 & 3,44 & $0,57 \mathrm{ef}$ \\
B5 (kompos paitan + pukan ayam) & 0,56 & 0,58 & $0,27 \mathrm{f}$ \\
B6 (kompos kulit durian + pukan ayam) & 0,00 & 0,55 & $0,31 \mathrm{f}$ \\
B7 (kompos TKKS + pukan ayam) & 0,62 & 0,00 & 4,06 \\
\hline Rataan & 3,90 & \\
\hline
\end{tabular}

Keterangan : Angka yang diikuti oleh huruf yang tidak sama berarti berbeda nyata menurut Uji DMRT pada taraf $5 \%$

Berdasarkan hasil penelitian dapat dilihat bahwa nilai Al-dd (Tabel 4) mempunyai hubungan dengan kejenuhan $\mathrm{Al}$ (Tabel 5), dengan menurunnya kandungan Al-dd tanah maka kejenuhan aluminiumnya juga akan menurun seiring dengan nilai Al-dd. Hal ini dapat dilihat bahwa perlakuan B6 (kompos kulit durian + pukan ayam) dengan nilai Al-dd sebesar 0,01 me/100g mempunyai kejenuhan Al sebesar 0,27 \% dengan kriteria sangan rendah. Menurut Anas [3] 
penambahan kompos kulit durian mampu menurunkan kejenuhan Al dan hasil penelitian Pontillas [12] menyatakan bahwa semua bahan organik mampu menurunkan kadar $\mathrm{Al}$ tanah.

\section{Kesimpulan}

Aplikasi beberapa bahan organik berpengaruh nyata meningkatkan $\mathrm{pH}$ tanah, P-tesedia, KTK serta menurunkan Al-dd dan kejenuhan Al. Semakin lama waktu inkubasi berpengaruh nyata menurunkan $\mathrm{pH}$ tanah, namun tidak berpengaruh nyata terhadap P-tersedia, KTK, Al-dd dan kejenuhan Al. Interaksi bahan organik dan lamanya inkubasi berpengaruh nyata menurunkan Al-dd namun tidak berpengaruh nyata terhadap pH, P-tersedia, KTK dan kejenuhan Al. Diperlukan penelitian lanjutan penambahan waktu inkubasi terhadap aplikasi bahan organik untuk mengetahui perubahan $\mathrm{pH}$ dan ketersediaan $\mathrm{P}$ dalam tanah Ultisol.

\section{Daftar Pustaka}

[1] Abdurachman, A. Dariah, dan Mulyani. 2008. Strategi dan Teknologi Pengelolaan Lahan Kering Mendukung Pengadaan Pangan Nasional. J. Litbang Pertanian 27(2):43-49.

[2] Adiwiganda, R., A. Purba., dan Z. Poeloengan. 1996. Pengolahan Tanah Areal Peremajaan Kelapa Sawit Berdasarkan Sifat Tanah Pada Tingkat Sub Grup (Macam). Warta PPKS. Vol. 4(1) : 9-22.

[3] Anas, I. 2000. Potensi Sampah Kota untuk Pertanian di Indonesia. Seminar dan Lokakarya Pengelolaan Sampah Organik untuk Mendukung Program Ketahanan Pangan dan Kelestarian Lahan Pertanian. Kongres MAPORINA, 6 -7 September 2000, Malang.

[4] Damanik, V. 2013. Pengaruh Pemberian Kompos Kulit Durian dan Kompos Kulit Kakao Pada Ultisol Terhadap Beberapa Aspek Kimia Kesuburan Tanah. Skripsi. Universitas Sumatera Utara. Medan.

[5] Darmosarkoro, W. Dan Winarna. 2003. Penggunaan TKS dan Kompos TKS untuk Meningkatkan Pertumbuhan dan Produksi Tanaman. Lahan dan Pemupukan Kelapa Sawit, Pusat Penelitian Kelapa Sawit, Medan. 1 : 181-194.

[6] Engelstad, O. P. 1997. Teknologi dan Penggunaan Pupuk. Terjemahan DH. Goenadi. Gadjah Mada University Press. Yogyakarta.

[7] Ginting, E. N. Dan S. Rahutomo. 2008. Pengaruh Kompos Tandan Kosong Kelapa Sawit Terhadap Produksi Tanaman Kelapa Sawit dan Perubahan Sifat Kimia Tanah. J. Penelitian Kelapa Sawit, 16 (3): 127-133.

[8] Harada, Y. and A. Inoko. Cation-exchange Properties of Soil Organic Matter. National Institute of Agricultural Science, Tokyo, Japan.

[9] Hardjowigeno, S. 2007. Ilmu Tanah. Edisi Baru. Akademika Pressindo. Jakarta.

[10] Manurung, R. H. 2013. Pengaruh Pemberian Kompos Kulit Durian pada Entisol, Inseptisol, dan Ultisol Terhadap Beberapa Aspek Kesuburan Tanah (pH, C Organik, dan N Total) serta Produksi Tanaman Jagung (Zea mays L.). Skripsi Ilmu Tanah. FP-USU, Medan.

[11] Mukhlis, Sarifuddin dan H. Hanum. 2011. Kimia Tanah Teori dan Aplikasi. USU Press. Medan.

[12] Pontillas, L. A. 2009. Soil Chemical Properties and Dry Matter Yield of Corn as Influenced by Organic Matter Amendment. State College. Katipunan.

[13] Riyaldi, 2000. Percepatan Proses Dekomposisi Serasah di Lapangan untuk Sumber Pupuk Organik. Media Perkebunan No. 22. Februari-Maret 2000.

[14] Scnitzer, M. 1991. Soil Organik Matter. The Next 75 Year Soil Science.

[15] Tan, K.H. 2010. Principles of Soil Chemistry Fourth Edition. CRC Press Tailor and Francis Croup. Boca Raton. London. New York. 362 p.

[16] Tisdale, S. L., W. L. Nelson., J. L. Havlin dan J. D. Beaton. 1999. Soil Fertility and Fertilizers : An Introduction to Nutrient Management. Prentice-Hall, Inc.New Jersey.

[17] Wiwie. 2011. Pengaruh Beberapa Kombinasi Pupuk Kandang Ayam dengan NPK (15 : 15 : 15) terhadap Pertumbuhan dan Hasil Markisa Ungu (Passiflora edulis var. Edulis sims). Universitas Andalas. Padang.

[18] Yue, W., X. Ding, S. Xue, S. Li, X. Liao and R. 2014. Wing. Effects of Oganic-Matter Application on Phosphorus Adsorption of Three Soil Parent Materials. Journal of Soil Science and Plant Nutrition. Guangdong Institute of Eco-Environmental and Soil Science, Guangzhou, China. 
